\title{
EFFECT OF DEBT MANAGEMENT ON INFRASTRUCTURAL DEVELOPMENT OF THE NIGERIA ECONOMY
}

\author{
Ozue Clement Chuks (M.Sc.) ${ }^{1}$, Okenwa C. Y. Ogbodo (PhD) ${ }^{2}$ \\ ${ }^{1}$ Audit Department, University of Delta, Agbor, Delta State. Nigeria. \\ ${ }^{2}$ Accountancy Department, Nnamdi Azikiwe University, Awka, Anambra State. Nigeria.
}

Article DOI: $\underline{\text { https://doi.org/10.36713/epra8481 }}$

DOI No: 10.36713/epra8481

\begin{abstract}
The study empirically examined the effect of debt management on infrastructural development of the Nigeria economy. Expost facto research design was adopted for the study. Data was collected through secondary sources from the archive of Central Bank of Nigeria (CBN) and Debt management Office of Nigeria (DMON). The data analysis was done using Ordinary Least Square (OLS) regression technique. The population of study consists of the federal government of Nigeria, the thirty- six state governments in Nigeria and the Federal Capital Territory (FCT) bringing the total population to thirty - eight (38). The same number serves as the sample size. The major findings showed that debt servicing and interest rate appeared with negative relationship on infrastructural development. It is recommended that government should apply appropriate policies with respect to debt variables for sustaining development in infrastructure.
\end{abstract}

KEY WORDS: Public debt management, infrastructural development.

\section{INTRODUCTION}

The emergence of an import oriented consumption pattern gave rise to external borrowing. Sourcing for hard currencies to finance the importation of goods and services promoted external borrowing. Secondly, borrowed funds were invested in unproductive ventures. The first loan ever contracted by the government of Nigeria was US\$ 13.1 million obtained from the Italian government in 1964 for the construction of Niger dam. From then, borrowing continued till the present day. External loans were contracted by the various tiers of government in Nigeria for the execution of developmental projects. The servicing of external loans in terms of the accrued interest and the principal loan affected balance of payment and infrastructural development of the country (Garba, 1995a).

In 1982, the collapsed of oil prices in the international oil market further aggravated the situation. Nigeria government were unable to liquidate her contracted loans and interest payment and penalty spiked up. This continued and the government stopped servicing her debt owed to Paris club of Nations simply because of their refusal to reschedule her loan profile. Nigeria economic planners came up with a policy that propelled further borrowing as a result of their rational thought that the country was in total blink of collapsing. During the oil boom period, there was total divestment in Agriculture and other revenue yielding ventures. Loans were contracted on the premise that the country would experience turn around in the oil industry that would resuscitate the international oil market. This never happened and it came to a time that that contracted loans equated with the national income. Interest on these loans kept soaring in a compounding manner (Garba, 1995b).

The Nigerian government in the quest for additional loans accepted stringent measures stipulated by International Monetary Fund (IMF) such as the devaluation of her currency (Naira). This measure has never helped the country to improve in her ability to liquidate the debt but rather created the problem of external debt crises. 
Financial reforms introduced in the country led to domestic borrowing. This reform begot the creation of Central Bank of Nigeria (CBN) and the marketable public securities used intensively for financing fiscal deficit. Instruments of domestic borrowing include Nigerian treasury bills and certificates, federal government development stocks, treasury bonds and of late Sukuk fund. Treasury bill accounted for $62 \%$ of Nigeria's domestic debt and this is as a result of roll over of matured securities. Treasury bond and development stock are also other domestic debt instrument used often times by the government to raise funds for developmental projects. Government budget has also been in deficit due to anticipation of projected revenue which were never achieved in full. In order to augment the available fund, government sees borrowing as the next available option for financing budget deficit. This is done through internal and external borrowing. Nigeria's debt profile has always high due to their inability to service and pay interest on the borrowed funds. Debt burden of the country has negative effect on her infrastructural development and this retard her progress wheel. Prudent debt management is the only means of promoting infrastructural development of the country (Uguru, 2015).

Nigeria debt management strategy which spans from 2020 to 2023 is instituted to guide the government in borrowing in the medium term based on the standard set by world bank and international monetary fund. This new debt strategy was developed for attaining government financial needs with minimum cost and risk, economic recovery growth plans, medium term expenditure framework and 2020 draft budget estimate. It was also done for the development of domestic capital market to enable the government and the private sector have access to long term loan and attract foreign investment (DMO, 2019).

\section{STATEMENT OF PROBLEM}

Debt management is a major challenge to developing economies of the world. In the first place, servicing of this debt has left so many of these countries under developed since it takes much of the fund that would have been channeled into her developmental project. Presently, in Nigeria debt servicing gulps over a trillion naira annually. The financing of long term projects that are not viable and productive with short term loan is another major problem confronting the country. Due to incessant saving and investment gap, local production and importation gap and budget deficit, Nigeria has continued to accept those stringent measures imposed on her by International Monetary Fund (IFM) for contracting fresh loans. These measures like the devaluation of her currency often retard growth and serves as a tool for welcoming debt crises. Debt servicing, interest rate and exchange rate devaluation may have effect on infrastructural development and other social services of the country (Onaolapo, 2015).

\section{OBJECTIVES OF THE STUDIES}

The main objective of the study is to examine the effect of debt management on infrastructural development of the Nigeria economy. The specific objectives are to:

- Examine the effect of debt servicing on infrastructural development of the Nigeria economy.

- Ascertain whether interest rate on loan has effect on infrastructural development of the country.

- Determine whether exchange rate devaluation affect infrastructural development of the country.

\section{RESEARCH QUESTIONS}

How does debt servicing affect infrastructural development of the country?

What effect does interest rate on loan have on infrastructural development?

To what extent does exchange rate devaluation affect infrastructural development on the country?

\section{RESEARCH HYPOTHESES}

Debt servicing has no significant effect on infrastructural development of the country.

Interest rate on loan has no significant effect on infrastructural development of the country.

Exchange rate devaluation has no significant effect on infrastructural development of the country.

\section{SCOPE OF THE STUDY}

The study comprises of the management of both external and internal debts of Nigeria between 2010 and 2020. This was done to review the effect of debt management on infrastructural development of the Nigeria economy within the above stated period. 


\section{LITERATURE REVIEW CONCEPT OF DEBT}

Debt is created through the process obtaining loan. It is the resource contracted by a country for public use which must be liquidated by the borrower country. It is a liability and equivalent to financial instrument. Debt has no generally accepted definition but it may be regarded as that owed legally by an individual or by a country (Alawneh, 2017).

\section{CONCEPT OF PUBLIC DEBT}

Funds borrowed by the government are termed public debt and it could be internal or external. Public loan is used by the government to bridge their financial gaps. Proper channeling of the borrowed can help build on infrastructure and achieve the social needs of the populace. Poor debt management retard infrastructural development thereby leaving the country improvised. High debt burden increases interest, leads to divestment and encroaches more on the needed funds for development. Nigeria public debt structure is made up of foreign or external loan and domestic or internal loan.

Domestic debt according to Odo, Ogonna and Anoke (2014) is a debt instrument used by the federal government and denominated in local currency. State government can also issue debt instrument to raise capital for development but this is limited in their ability to issue such. Domestic debt is also the gross liability of the government. It is a collateral used in the financial markets that plays an important role of monetary policy implementation.

External debt according to Oladokun (2015) is a loan owed to persons, public and private institutions that are abode outside the shore of Nigeria. It consists of loan from IMF, International Capital Market (ICM)- multilateral creditors, Paris club, London club.

\section{CONCEPT OF PUBLIC DEBT MANAGEMENT}

Public debt management is carried out by establishing and executing plans that aid in managing government's debt in order to raise the required capital at low cost from medium term to long term basis with efficient management of risks associated with it. The objective emanating from this definition is to meet government borrowing requirement, borrowing at low cost, manage the risks associated with it and maintaining government debt securities. All these are achieved through proper execution of debt management strategy.

\section{PURPOSE OF INITIATING 2020 TO 2023 DEBT MANAGEMENT STRATEGY}

The major reasons for introducing this debt strategy is outlined below:

(a) To ensure that both the domestic and external borrowing are in line the medium term expenditure framework and the appropriation Acts in place.

(b) To ensure a reduction in the cost of servicing the debt measured by the interest payment ratio to the revenue ratio.

(c) Controlling the risks of refinancing and that of foreign exchange.

(d) Full utilization of loans granted to Nigeria by the creditor nations so as to be able to gain access to further loans.

(e) The use of long term debt instruments should be encouraged (DMO, 2019).

\section{CONCEPT OF INFRASTRUCTURE}

Jacobson and Tarr (1995) defined infrastructural services as the structures and networks that frame and bind together modern cities and metropolitan areas and makes it possible to undertake social and economic activities.

According to African Development Bank (1999) infrastructure is an umbrella term for all the activities referred to as "social overhead capital" that includes these services;

1. Public activities such as power, telecommunication, pipe- borne water supply, sanitation and sewerage, solid waste collection the disposal.

2. Public works such as roads and major dams and carnal works for irrigation and drainage.

3. Transport sector such as urban and interurban railways, urban transport, ports and water ways and airports.

\section{GOALS OF DEBT MANAGEMENT}

The major reason for managing debt is to equate government financial needs with the payment plans at a very low cost. This goal leads to the development of debt management strategy that needs to be updated annually. Strategy development and implementation is important in developing governance framework for debt management. The 
structure of debt management policies can positively or negatively affect infrastructural development in the country. The legislative aspect is meant to provide the needed framework for contracting loans and at the same time provide guidance on how to manage debt (Okonjo- Iweala, 2005).

\section{GLOBAL STRATEGY FOR MANAGING DEBT}

The strategies adopted globally to manage debt crises are as itemized below:

(1) FREE MARKET SOLUTION: Highly indebted countries that are unable to service their loans are prevented from contracting further loans. This method favours some quarters and this makes it a no credit solution to debt crises.

(2) ADJUSTMENT BY DEBTOR NATIONS: This involves stimulating export to enable the countries earn more foreign exchange, reducing import to serve the foreign exchange earned, opening up the domestic economy (deregulation of interest rates and the abolition of government subsidies). This method has negative effect on the economy.

(3) ADJUSTMENT BY THE ADVANCED NATIONS: Developed nations are required to take proactive steps by reducing the debt burden of developing nations. It requires the substantial cancellation of developing nations debt and helping these indebted developing countries to develop their economy.

(4) RESCHEDULING: It simply means postponing the interest charges and the principal repayment on due loans since these loans has become unbearable for the debtor nations. It is the act of allowing indebted nations more time to put their economy in good working condition.

\section{NIGERIA STRATEGY FOR MANAGING PUBLIC DEBT}

The following are the strategies used by the Nigerian government for managing public debt

(1) ESTABLISHMENT OF DEBT MANAGEMENT OFFICE: The relief from debt burden became priority when former President Olusegun Obasanjo assumed office in 1999. An agency known as debt management office was established in 2001 as the only agency responsible for managing the country's debt profile. The establishment of debt management office consolidated debt management as a single organization entrusted with the power of properly coordinating Nigeria's debt service and payment plans, and advising on negotiations as well whether there will be need for further borrowing. The roles performed by the debt management office, the central bank of Nigeria and the federal ministry of finance in debt management is important if the country must liquidate debt liability. This has not been achieved because the strategy in place is insufficient. The Central Bank of Nigeria (CBN) is the only financial institution that negotiate for loan on behalf of the government and it is guided by the financial regulation and legislation of the country. DMO is responsible debt technical and analytical work in the area of costs and risk of debt management considering the macro- economic and the market factor. It is the responsibility of DMO to send the drafted debt management strategy to the executive arm of government- acting as the advisory body

(2) EMBARGO ON NEW LOANS: This was done to check for further borrowing and the escalating debt profile. Embargo was placed on further borrowings of both the federal and state governments.

(3) DEBT RESTRUCTURING: This is done by reducing the burden of the existing debt through refinancing, rescheduling, bring back, issuing collateral bonds and the provision of new money.

(4) REDEMPTION OF PAYMENT: This is done through the payment interest and principal on due debts and managing the sinking fund set up for debt payment purpose. The Central Bank of Nigeria guarantees debt security by underwriting the unsubscribe securities and provide a secondary market for the divestment of public holdings.

\section{RISK WITH NIGERIA DEBT MANAGEMENT}

The risks associated with Nigeria debt portfolio are listed below:

Solvency Risks: This risk occurs when it is observed that a country may likely become insolvent and this is associated with heavy indebtedness that will be difficult to liquidate especially as it relates to external debt.

Market Risk: Changes in market prices have impact on the cost of servicing government debt. The categories of risks covered here are interest, exchange and commodity risks.

Rollover Risk: Risks of government inability to roll over her outstanding debts to future date.

Refinancing Risk: This is the inability of the borrower to refinance or roll the existing debt to a future date as a result of the rising interest rate. 
Credit Risk: This is risk of defaulting in the payment of due debt due to high bank exposure.

Liquidity Risk: here the liquid assets diminish quickly due to the borrower's inability to raise the required capital from borrowing on short term period.

DEBT INSTRUMENTS

Debt Servicing: Debt are serviced by the debtor nation to avoid the risk of paying penalties and to also maintain the bilateral debt service to the world agreement entered into by both the debtor and the creditor nations. Reasonable level of resources is set aside and released on time for effecting debt service payment. Debt service to the world is every fifteen (15) days while that of the African Development Bank (ADB) is settled frequently. Stiff penalty in the event of default is melted out every thirty (30) days after the due date. Failure to service debt obligation will result in the prohibition of further borrowing, suspension of disbursement of loans granted to the borrower and the suspension from contracting new loans.

Interest Capitalization: This involves the compounding of interest on the capital and the accumulated interest that has not been settled.

\section{NIGERIA DEBT PROFILE}

Nigeria's Total Public Debt owed internally and externally was $\$ 24,387,071.74$ Trillion (US\$79,436.72 million), as at December 31, 2018. The detail is shown below.

\section{Figure 1}

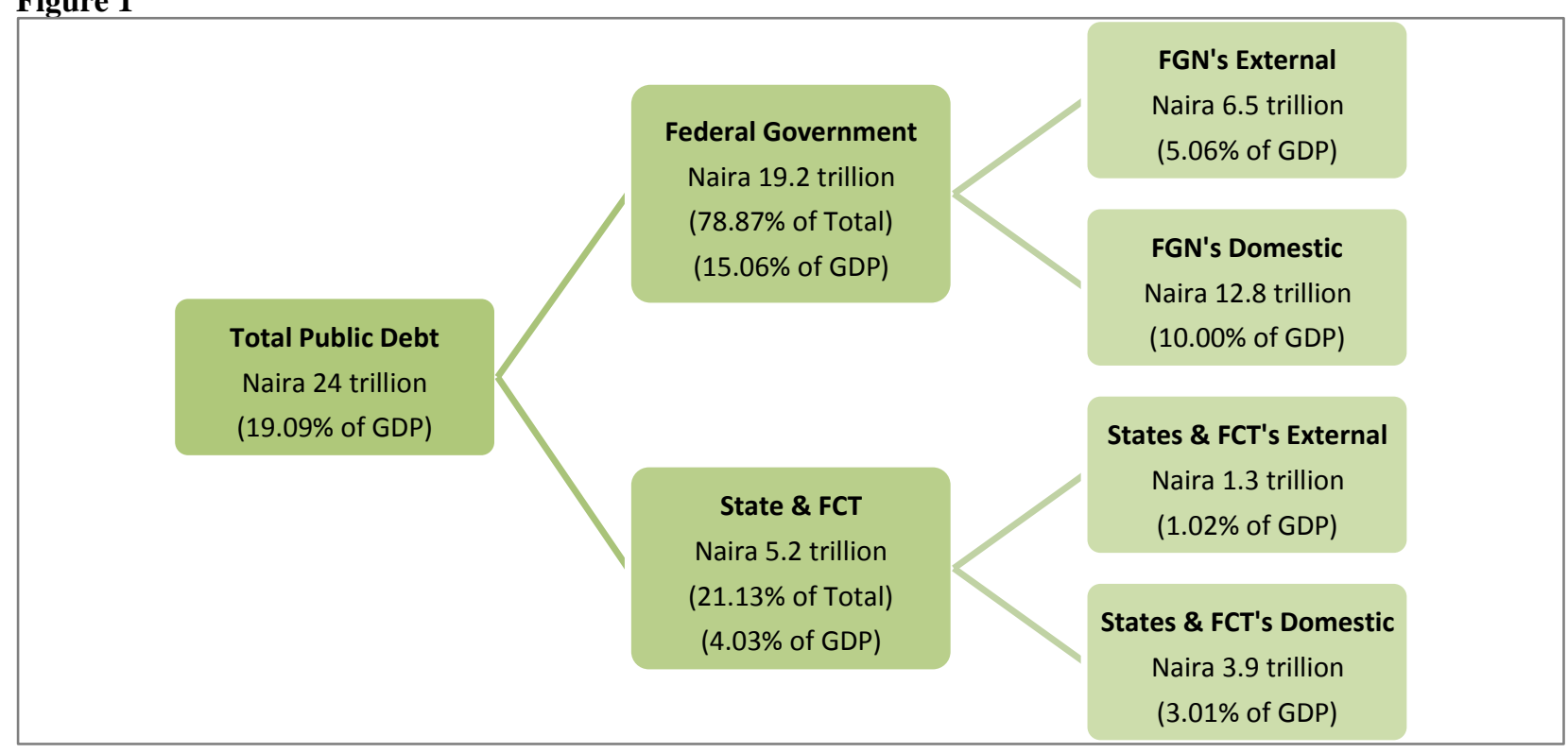

Source: Debt Management Office (DMO).

\section{Empirical Review}

Alawneh (2017) examined the effect of capital expenditure, current expenditure, external and internal public debt on taxes in Jordan. The study covered the period 2001-2014 and the data used in the study was from secondary source. The gathered data was analyzed using the ordinary least square estimation technique. The findings showed that there is a statistically significant influence on both the capital expenditure and the current expenditure. The study also revealed that external and internal public debt has a negative effect on taxes in Jordan. It was recommended that the government should use non-traditional alternatives to finance capital expenditure rather than contracting loan from external source.

Oladokun (2015) examined the causal relationship between Public Expenditure and National Debt in Nigeria. The study considered 1980 to 2012 and used data obtained from secondary source. The obtained data was analyzed using the ordinary least square estimation technique. The results of the study showed that a causal relationship exists between public expenditure and domestic debt, an indication that borrowed funds were used to finance shortfall in recurrent expenditure. The study concluded that corruption in high places, misapplication of public funds, and poor administrative machinery has slowed the growth of the public sector leading divestments in the economy. 
Onaolapo and Kayode (2015). Examined the effect of external debt management in economic growth. The objective was to examine the impact of external debt management in Economic growth of Nigeria within the period of 2000 2009. The study used secondary data sourced from journals, Magazine and Central Bank of Nigeria statistical Bulletin Collected data was analyzed using both qualitative and quantitative approaches. The qualitative approach involves the use of descriptive analysis in which percentages are used to summarize the findings. Quantitative approach involved the use of both the descriptive and inferential statistics. Findings showed that there is significant relationship between external debt and economic growth.

Odo, Ogonna, and Anoke (2014) analyzed the causal relationship between public debt and public expenditure in Nigeria from 1980 to 2015. Data used for the study was sourced secondarily from central bank of Nigeria statistical bulletin. The gathered data was analyzed using Johansen co integration test and vector error correction model. The findings revealed that there is a long run relationship between government expenditure and public debt. The findings also showed that government revenue and recurrent expenditure has significant positive relationship with public debt in the Nigeria economy.

Kgakge-Tabengwa (2014) analyzed the effect of shocks on public debt and government expenditure in the development of human capital and growth in selected developing countries from 1980-2013. The study findings showed that heavy public debt burden affect human capital growth by encroaching on government available resources that would have been channeled into human capital development. The study concluded that developing countries with debt burden and low revenue will find it difficult to develop human capital. The study recommended the adoption of public debt management strategies and the control of government expenditure frameworks.

\section{METHODOLODY}

The study adopted Ex- post facto research design. It was adopted because the variables were not manipulated by the researcher.

The population of the study consists of the federal government of Nigeria, states government and the federal capital territory. This brought the total population to thirty- nine.

Since the population is not too large, the researcher used all the study population size (government at the federal and states level).

\section{Data and Estimation Techniques}

The data used in this research are in time series covering the period 2010 to 2020 . The main source of data used in this study was from secondary source obtained from Central Bank of Nigeria statistical bulletins (CBN), debt service statement from Debt Management Office (DMO), National Bureau of Statistics (NBS) and cognate publications. The ordinary Least Square (OLS) regression technique was adopted as the estimation technique for this study.

\section{MODEL SPECIFICATION}

The model specification was based on the objective of the study. The model was supported with some debt overhang variables for both the internal and external debt. This debt overhang was captured based on this single linear regression model adopted below:

INFD $=\int(D S E, I N T$, EXCD)

The model from equation 1 can be specified as

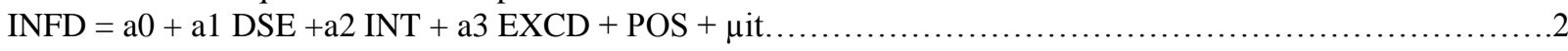

From the logarithm, the model becomes

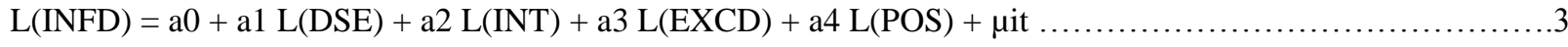

Where,

$\mathrm{L}(\mathrm{INFD})=\log$ of infrastructural development.

$\mathrm{L}(\mathrm{DSE})=\log$ of debt servicing.

$\mathrm{L}(\mathrm{INT})=\log$ of interest rate on loan.

$\mathrm{L}(\mathrm{EXCD})=\log$ of exchange rate devaluation.

POS = dummy variable used to cater for political instability in the model which may take the form 0 for political instability and 1 for stability in politics.

$\mu$ it $=$ error term with zero mean.

$\mathrm{A} 0-\mathrm{a} 4$ are parameters for estimating with $\mathrm{a} 0$ as the constant. 


\section{ESTIMATION PROCEEDURE}

Ordinary least square estimation method was adopted for this study. The OLS has the Best Linear Unbiased Estimator (BLUE), which is efficient, consistent, sufficient and unbiased estimators. OLS was used because of its standard approach to set of equations with more equation than the unknown.

\section{TECHNIQUE FOR EVALUATION}

The result from the ordinary least square model will be evaluated based on economic, statistical and economic criteria.

Economic Criterion: The interest here are the signs and sizes of the coefficient.

Statistical Criterion: The significance of the Aprori expectation is confirmed here. They include t- test, standard error, $\mathrm{R}$ and the adjusted $\mathrm{R}^{2}$. $\mathrm{T}$ - test explains how the individual variables used in the study are important in explaining the dependent variables. $\mathrm{R}^{2}$ shows the percentage of the dependent variable that has been explained by the explanatory variable.

Econometric Criterion: This involves carrying out residual normality test, heteroscedasticity test, multicollinearity test, autocorrelation test.

\section{INTERPRETATION AND EVALUATION OF RESULTS}

\section{Evaluation based on Economic Criteria}

The estimated parameters were tested based on the economic theory to determine their status. To show whether it conform with the Aprori expectation.

From the ordinary square result table, the result revealed that debt servicing as a ratio of GDP has a negative relationship with infrastructural development. This is consistent with the theory that an increase in debt burden increases the debt service, which automatically encroaches the available resources for infrastructural development.

In furtherance, the result also revealed that interest on loan repayable has a negative relationship with infrastructural development which is consistent with debt theory that as interest rate increases, investment on infrastructure falls. For the exchange rate, the result showed that an increase in exchange rate increases infrastructural development by $39 \%$.

\section{Evaluation based on Statistical Criteria}

T- test was used to measure the impact of the explanatory variables on the dependent variables. Exchange rate has no significant relationship with infrastructural development given t- value of 1.98550 which is lower than the rule of thumb of two (2) and probability of 0.0577. Debt servicing and interest rate showed a significant relationship with infrastructural development. The result showed t- value of -2.418401 and -2.556265 which is higher than the rule of thumb and probability of 0.0229 and 0.0168 confirms this.

\section{Evaluation based on Econometric Criteria}

Under this, the autocorrelation test showed slight autocorrelation given Durbin Watson of 1.592700. Heteroscedasticity test showed error term with F statistics of 1.171227.

Table 1: Summary of OLS Result

\begin{tabular}{|c|c|c|c|c|}
\hline \multicolumn{5}{|c|}{ Dependent Variable L(INFD) } \\
\hline Independent Variables & Coefficients & Standard Error & T- Statistics & Prob \\
\hline $\mathrm{C}$ & 0.072249 & 1.056515 & 0.068385 & 0.9460 \\
\hline Log (debt servicing) & -0.379274 & 0.156828 & $-2.418401 \square$ & 0.0229 \\
\hline Log (INT) & -1.030667 & 0.403192 & $-2.556265 \square$ & 0.0168 \\
\hline $\log (\mathrm{EXR})$ & 0.390321 & 0.196581 & 1.985550 & 0.0577 \\
\hline POS & -0.655113 & 0.239173 & $-2.739081 \square$ & 0.0110 \\
\hline $\mathrm{R}^{2}$ & 0.896579 & & & \\
\hline $\mathrm{R}^{2}$ (Adjusted) & 0.868735 & & & \\
\hline F (Statistics) & 32.19996 & & & \\
\hline F (Probability) & 0.00000 & & & \\
\hline DW & 1.592700 & & & \\
\hline Level of significance & $5 \%$ & & & \\
\hline
\end{tabular}


$(\square)$ asterisks indicate coefficients significant at $5 \%$ level of significance.

\section{HYPOTHESES}

The result stated above is used in the evaluation of the hypotheses of the study.

Hypothesis One: Debt servicing has no significant effect on infrastructural development in Nigeria.

Conclusion: The result of the ordinary least square showed that there is a negative linear relationship between debt servicing and infrastructural development. Thus we accept the null hypothesis which stated that there is negative relationship between debt servicing and infrastructural development in Nigeria.

Hypothesis Two: Interest rate on loan has no significant effect on infrastructural development in Nigeria.

Conclusion: We affirm from the ordinary least square result that interest on loan has no significant effect on infrastructural development in Nigeria.

Hypothesis Three: Exchange rate devaluation has no significant effect on infrastructural development of the Nigeria economy.

Conclusion: The result of the ordinary least square revealed that there is positive relationship between exchange rate and infrastructural development. We therefore conclude that exchange rate devaluation has effect on infrastructural development in Nigeria.

\section{POLICY IMPLICATION}

The study objective was to examine the effect of debt management on infrastructural development of the Nigeria economy. the policy implication of the study was based on the result obtained from the ordinary least square estimate.

The findings of negative significant relationship between debt servicing, interest rate on loan and infrastructural development is detriment to the development and growth of the economy. This result is in line with the findings obtained by Kgakge- Tabengwa (2014) that huge debt affects the development of the economy. Although this study is on the effect of shock on public debt and the development of human capital but can still be applied to this study since the two studies focused on debt.

Exchange rate devaluation showed a positive significant relationship with infrastructural development of the Nigeria economy. This is in line with the findings obtained from Odo et al (2014) that government revenue and recurrent expenditure has positive significant relationship with public debt in Nigeria.

\section{CONCLUSION AND RECOMMENDATION}

Nigeria economy depend on borrowing to finance infrastructural development. Both internal and external borrowings have effect on the economy. The reason for government borrowing is attributable to deficit budget financing and the implementation of monetary policy. The problems remained that there was no proper guideline for loan contractual obligation. Financial crises have effect on infrastructural development and this translate into debt burden. Government borrowing ought to be an important source of fund for developmental investment but some borrow to finance recurrent expenditure.

The study concluded that debt servicing, interest rate and exchange rate devaluation have influence on debt management that could affect infrastructural development in Nigeria either positively or negatively. The study recommended that the government should apply appropriate policies with respect to debt variables for sustainable development in infrastructure.

\section{REFERENCES}

1. Ajayi, R. (2003). On the Simultaneous Interactions of External Debt, Exchange Rates, and Other Macroeconomic Variables: The Case of Nigeria. Centre for Economic Research on Africa Research Series, No. 23.

2. Alawneh, A. (2017). The Impact of Public Expenditure and Public Debt on Taxes: A Case Study of Jordan. Accounting and Finance Research, 6(3), 10-23.

3. Chenery, H. (1996). Economic growth in an open developing economy: The Role of structure and demand, Cheltenham: Edward Elgar.

4. Debt Management Office (2005). Debt Management Office Annual Report. Abuja: Federal Government of Nigeria

5. Available on-line at www.dmo.gov.ng

6. Debt Management Office (2013). Debt Management Office Annual Report. Abuja: Federal Government of Nigeria

7. Available on-line at www.dmo.gov.ng

8. Eaton, J. (1993). Sovereign Debt: A Primer. World Bank Economic Review, 7(2), 137-172. 
9. Fosu, A. K. (2007). Fiscal allocation for education in sub-Saharan Africa: Implications of the external debt service constraint. World Development, 35(4), 702-713.

10. Fosu, A. K. (2008). Implications of the external debt-servicing constraint for public health expenditure in sub-Saharan Africa. Oxford Development Studies, 36(4), 363-377.

11. Fosu, A. K. (2010). The external debt-servicing constraint and public expenditure composition in sub-Saharan Africa.

12. African Development Review, 22(3), 378-393.

13. Garba, A.G. (1995a). Political Change, External Shocks and Federal Fiscal Policy Operations in Nigeria 1975-1993.

14. Garba, A.G. (1995b). The Determinants of Nigerian Federal Government Expenditure1970-1993. A final report submitted to the African Economic Research Consortium (AERC), Nairobi, Kenya.

15. International Monetary Fund (2009a). Nigeria: 2009 Article IV consultation, IMF Country Report No. 09/315, Washington, DC: IMF.

16. International Monetary Fund (2009b), International financial statistics, online, http://www.imfstatistics.org/imf/

17. Jacobson, C. A. and Tarr, J. A. (1995). Ownership and financing of infrastructure. World bank research working paper. 1466.

18. Kgakge-Tabengwa, G. G (2014). Impact of Shocks to Public Debt and Government Expenditure on Human Capital and Growth in Developing Countries. Journal of Economics and Behavioral Studies, 6(1), 44-67.

19. Krugman Paul. (1988). Financing vs. Forgiving a debt overhang: Some Analytic notes. Journal of Development Economics, 29, 253-268.

20. Mah, G., Mukkudem-Petersen, J., Miruka, C., and Petersen, M.A. (2013). The Impact of Government Expenditure on the Greek Government Debt: An Econometric Analysis. Mediterranean Journal of Social Sciences, 4(3), 323-330.

21. Odo, S. I., Ogonna, I. C., and Anoke, C. I. (2014). Public Debt and Public Expenditure in Nigeria: A Causality Analysis. Research Journal of Finance and Accounting, 7(10), 27-38.

22. Okonjo-Iweala, N. (2005). Why Nigeria Deserves Debt Relief' Abuja: Federal Government of Nigeria Presidency of Nigeria

23. $2007 a$ 'M\&E for Accountability: The Case of Nigeria's VPF. Paper Presented at the African Evaluation Association conference on 18th January 2007 in Niamey, Niger Available on-line at: www.newscentre.bham.ac.uk/debtrelief/index.shtml

24. Oladokun, O. O. (2015). Causal Relationship between Public Debts and Public Expenditure in Nigeria. International Journal of Management and Applied Science, 1(8), 68-79.

25. Onaolapo, A, A. \& Kayode, S. O. (2015). Impact of external debt management in economic growth. A lesson from

26. Nigeria. Research journal of finance and accounting, 6(5).

27. Shabbir, S. and Yasin, H. M. (2015). Implications of Public External Debt for Social Spending: A Case Study of Selected Asian Developing Countries. The Lahore Journal of Economics, 20(1), 71-103.

28. Sinha P., Arora V., and Bansal V. (2011). Determinants of public debt for middle income and high income group countries muenchen.de/32079/1/MPRA_paper_32079.pdf. Data access on 14 June 2018.

29. Šimović, H. (2017). Impact of public debt (un)sustainability on fiscal policy effectiveness in Croatia. E F Z G Working paper Series, No. 17-05, 1-17.

30. This Day newspaper November 5th 2005 debt relief: House Raises Questions Over US\$12.4b 9(3859), 1-17.

31. Uguru, L. C. (2015). The Link between Public Debt and Government Expenditure Pattern: The Nigeria Experience. IOSR Journal of Business and Management, 18(l), 37-41.

32. OLS ESTIMATE OF DEBT VARIABLES ON INFRASTRUCTURAL DEVELOPMENT

Dependent variable: $L(I N F D)$ 
Method: Least square

Date: 10/8/21 Time: 10:35

Sample: 2015- 2020

Included observation: 5

\begin{tabular}{lcllc}
\hline \multicolumn{1}{c}{ Variable } & Coefficient & Std. Error & t- Statistics & Prob. \\
\hline \multicolumn{1}{c}{ C } & 0.072249 & 1.056515 & 0.068385 & 0.9460 \\
LOG (DSGDP) & -0.379274 & 0.156828 & -2.418401 & 0.0229 \\
LOG (INT) & -1.030667 & 0.403192 & -2.556265 & 0.0168 \\
LOG (EXR) & 0.390321 & 0.196581 & 1.985550 & 0.0577 \\
POS & -0.655113 & 0.239173 & -2.739081 & 0.0110 \\
& & & \\
\hline R. Squared & 0.896579 & Mean dependent variable & -1.586104 \\
Adjusted R Square & 0.868735 & S. D. dependent variable & 1.331557 \\
S. E. of regression & 0.482430 & Akaike info. Criterion & 1.582363 \\
Sum squared resid & 6.051210 & Schwarz criterion & 1.941507 \\
Log likelihood & -18.90017 & F- statistics & 32.19996 \\
Durbin- Watson stat. & 1.592700 & Prob (F- statistics). & 0.000000 \\
\hline
\end{tabular}

\begin{tabular}{lccccc}
\multicolumn{7}{l}{ DESCRIPTIVE STATISTICS OF THE VARIABLES OF THE STUDY } \\
& LOG (INFD). & LOG (DSE). & LOG (INT). & LOG (EXCD). & POS. \\
Mean & -1.586104 & -2.710155 & 2.320124 & 2.093982 & 0.441176 \\
Median & -1.880398 & -2.528432 & 2.555240 & 2.188987 & 0.000000 \\
Maximum & 0.534754 & -0.214817 & 3.258097 & 4.898138 & 1.000000 \\
Minimum & -3.801548 & -5.522087 & 1.252763 & -0.597837 & 0.000000 \\
Std. dev. & 1.331557 & 1.799803 & 0.578065 & 2.174094 & 0.503995 \\
Skewness & 0.025524 & -0.083630 & -0.524636 & 0.024527 & 0.236940 \\
Kurtosis & 1.717020 & 1.600473 & 1.885150 & 1.416250 & 1.056140 \\
Jarque- Bera & 2.335579 & 2.814423 & 3.320470 & 3.556782 & 5.671132 \\
Probability & 0.311054 & 0.244825 & 0.190094 & 0.168910 & 0.058685 \\
Observation & 10 & 10 & 10 & 10 & 10
\end{tabular}

